\title{
THE DYNAMICS OF WAYANG GOLEK IN PANDEMIC AND GLOBALIZATION: TRADITIONAL ART SUSTAINABILITY
}

\author{
Mohammad Rindu Fajar Islamy', Aam Abdussalam ${ }^{1}$, Giani Adzkia ${ }^{2}$ \\ ${ }^{1}$ Universitas Pendidikan Indonesia, Bandung, Indonesia \\ ${ }^{2}$ Chubu Gakuin University, Gifu, Japan \\ Email: fajarislam2000@upi.edu
}

Received: September 4, 2021

Accepted: November 14, 2021

\section{Abstract}

This research aims to explore the dynamics of wayang golek art and to highlight its sustainability in the future. Modernity, the acceleration of technological devices and globalization wave in the last two decades, transfers great pressure on traditional arts and culture. Wayang Golek, a performing art originally from West Java, has recently received a fairly strong wave of resistance due to changes in the social culture which is mainly leading to modernity. By using a qualitative approach, data collection techniques were carried out by interviewing two main players as the puppeteers of Wayang Golek. The data analysis uses the theory of Miles and Hubberman, and the theoretical review of Islamic studies. The results of the study show that 1) Wayang Golek has unique characteristics, where the talent needed tends to go through the "inheritance" tradition, 2) Wayang Golek can be a bridge for internalizing religious and humanist values for the community through unique stories based on custom, 3) the restriction of Wayang Golek performance due to the Covid-19 pandemic leads the puppeteers to be more creative to survive, such as creating videos and uploading them in YouTube and other social media, and 4) the preservation of this art depends on the serious attention of all parties, from the government, regional officials, and the community.

el Harakah Jurnal Budaya Islam Vol. 23 No. 2, 2021 
Studi penelitian ini bertujuan untuk mengeskplorasi dinamika kesenian wayang golek, serta menyoroti keberlangsungan 'hidup' seni tradisional wayang golek dimasa yang akan datang. Era modernitas, akselerasi perangkat teknologi dan gelombang arus globalisasi dalam dua dekade terakhir, memberikan tekanan hebat pada wilayah seni dan budaya tradisional. Wayang Golek sebuah seni pertunjukkan yang berasal dari Jawa Barat akhir-akhir ini mengalami gelombang resistensi cukup kuat imbas dari perubahan kultur sosial masyarakat yang bergerak kearah modernitas. Dengan menggunakan pendekatan kualitatif, teknik pengumpulan data dilakukan dengan wawancara terhadap dua pemain utama sebagai "Dalang" Wayang Golek, observasi dan dokumentasi. Adapun analisis data menggunakan teori Miles dan Hubberman, dan kajian teoritis Islamic studies. Hasil penelitian menunjukkan bahwa 1) Seni Wayang Golek memiliki karakteristik unik, dimana bakat yang dibutuhkan cenderung melalui tradisi "warisan", 2) Wayang Golek dapat menjadi jembatan internalisasi nilai-nilai religius dan humanis bagi masyarakat melalui cerita-cerita unik berbasis adat, 3) dilarangnya pagelaran Wayang Golek akibat pandemi Covid-19 membuat para dalang lebih kreatif untuk bertahan, seperti membuat video dan menunggahnya ke YouTube dan media sosial yang lain, dan 4) Kelestarian kesenian ini bergantung terhadap perhatian serius semua pihak baik dari pemerintah, pejabat daerah, maupun masyarakat.

Keywords: Traditional Arts; Wayang Golek; Covid-19 Pandemic

\section{Introduction}

The Corona Virus (COVID-19) outbreak, which shocked public at the end of 2019 in Wuhan, China (Nishiura et al., 2020). It affected the whole concerning sectors of life, from education, tourism, culture, entertainment, and even the shopping center. In addition, according to UNESCO, there have been at least 1.5 billion more students affected by the Covid-19 pandemic. School and university suspense have triggered anxiety, leading to a complex educational problem among practitioners (de Jonge et al., 2020; Ellis et al., 2020; Kalloo et al., 2020; Kidd \& Murray, 2020; Varea \& González-Calvo, 2020; Wang \& DeLaquil, 2020). Besides, the Covid-19 pandemic has generated negative impact on a number of cultural practitioners due to the lack of income after the release of the government policy to close and restrict any shows and entertainment to anticipate the spread of the virus.

In addition, national and international scientists project a great transformation in the joints of human life in the last two decades due to 
the penetration of globalization on a global scale (Al-Rawashdeh, 2014; Law \& Ho, 2009; Utsumi, 2006). In a sociological study, Elbrow et al. (1994) highlighted the impact of globalization bringing into the fragmentation of cultural concepts that imply for the structuring of new forms and types of community. This research obviously further emphasizes the mindset, political policy, economy, education system, and culture of modern society as a result of globalization (London, 2010; Mah, 2002; Thompson, 2019). Besides, at the same time, cultural arts receive another hit from the outbreak of the Covid-19 pandemic in the last three years (Albarello et al., 2020; Zhang et al., 2020).

One of the traditional arts deemed to be potentially destroyed is Wayang Golek, which was once popular among Sundanese, West Java. It begins to be shifted by contemporary modern art (Rianta \& Masturoh, 2013). The modern arts deemed to suit the interest of millennials are modern dances, pop arts, theater and dramatic arts, and others. Some experts denoted that that modern dance rose up in the 20th century which was mostly transmitted by great dancers from Western countries to the United States. It is quite often that the modern dances we usually watch on TV adorn programs accompanied by music. Modern pop dances are characterized into several popular styles: 1) Blood-Elf Dance, 2) Break Dance, 3) Robot Dance, 4) Moonwalk Dance, and 5) Shuffle Dance. Some styles are sometimes modified and developed from the traditional to the modern by not only experts but also students at schools to enliven the art performances. The presence of several modern applications, such as TikTok has even contributed to increasing the publicss interest in exposing their creativity in the modern art.

Rosyadi argued that the art of Wayang Golek has begun to shift in the current era even though the show still adopt the classic stories of Mahabrata and Rayamana (Rosyadi, 2009). In general, this art performance is often contested in big cities, such as Cirebon, Garut, Bandung, Ciamis, Tasikmalaya, and other cities in West Java. Wayang Golek has gone through a very long journey with indefinite origin. This art is closely related to the characteristics of folk entertainment. The writers perceive that the popularity of Wayang Golek cannot be separated from the role of Sunan Kudus in the 16th century, in which he made seventy pieces of Wayang Purwo with Menak stories followed by Gamelan Salendro. Then, in the early 1840, it began to appear in the public sphere with new figures, such as Ramayana and Mahabrata whose characters are often known as Wayang Golek Purwa. Sutarno, one of the art observers, stated that Wayang Golek art was initiated by Dalem Karang Anyar (Wiranata

el Harakah Jurnal Budaya Islam Vol. 23 No. 2, 2021 
Koesoemah III). He and Ki Darman, a leather craftsman from Tegal, initiated the manufacture of Wayang art from wood. The main source of this art is believed by local people to come from Mahabharata and Ramayana stories. At the end of the 19th century, the art of Wayang Golek had a good role in forming a positive character for the community (Rianta \& Masturoh, 2013), where the process of internalizing wise values was instilled in this performance. Currently, several areas in West Java, especially Sundanese, still maintain this art, so it is not lost for globalization.

It is necessary for Puppet show to preserve. According to Priyanto (2020), Wayang Golek show is full of elements of drama, sound, literature, music, motion, and fine arts, which means that it has a variety of arts which contribute greatly to society in terms of knowledge, insight, culture, and local economy (Cohen, 2007; Nalan, 2016; Priyanto, 2020; Setiawan, 2019; Subiyantoro, 2017). Furthermore, he urged that the art of Wayang Golek seems to have helped boost regional economic income, for example in Saung Angklung Udjo (SAU) due to the large number of tourists, both domestic and foreign, who are interested in watching this traditional art (Priyanto, 2020). Indeed, in the tourism industry, to attract people to visit an area, a person must do innovative and creative ways, one of which is promoting the traditional arts of the local community. If Wayang Golek art cannot compete with modern arts, it is possible that this art will only leave the history in the future (Rosyadi, 2009). Currently, the practitioners of Wayang Golek art seem to innovate a little where they do not only rely on the income from performances but they also participate in creating souvenir items that can be sold to tourists.

This study seeks to explore the dynamics of the development of traditional Wayang Golek art culture with a bottom-up mode. It is initially represented by Dalang (puppeteer) who plays an important role for the preservation of this culture. It discusses the sustainability of traditional arts in the future in general and the dynamics of Wayang Golek in particular.

Researches related to Wayang Golek have been widely studied by local and international researchers, yet they mostly focus on describing its performances and linking them to the tourism aspects (Dewi, 2018; Hasanah, 2019; Lis, 2014; Nalan, 2016; Poplawska, 2004; Widjajanto, 2009; Widyastutieningrum, 2018). This study seeks to strengthen the findings related to the position of Wayang Golek in the context of culture and tourism. Our emphasis is on the preservation of traditional cultures in the future as a result of the recent cultural shift among modern society. It could serve as a fundamental basis 
for cultural practitioners to take appropriate and innovative policies so that local cultures do not obsolete in the future.

\section{Method}

This study employed a qualitative descriptive approach. The data were collected through structured interviews, observation, and documentation on two puppeteers of Wayang Golek. They had been involved in the world of Wayang Golek for a long time. The instrument of the interview contained ten questions. The interview results and collected data were then analyzed by using the theory of Miles and Huberman (1994) with four-stage framework; data reduction, data presentation, data display, and conclusion drawing/ verification. The flow of data analysis can be seen in the image below:

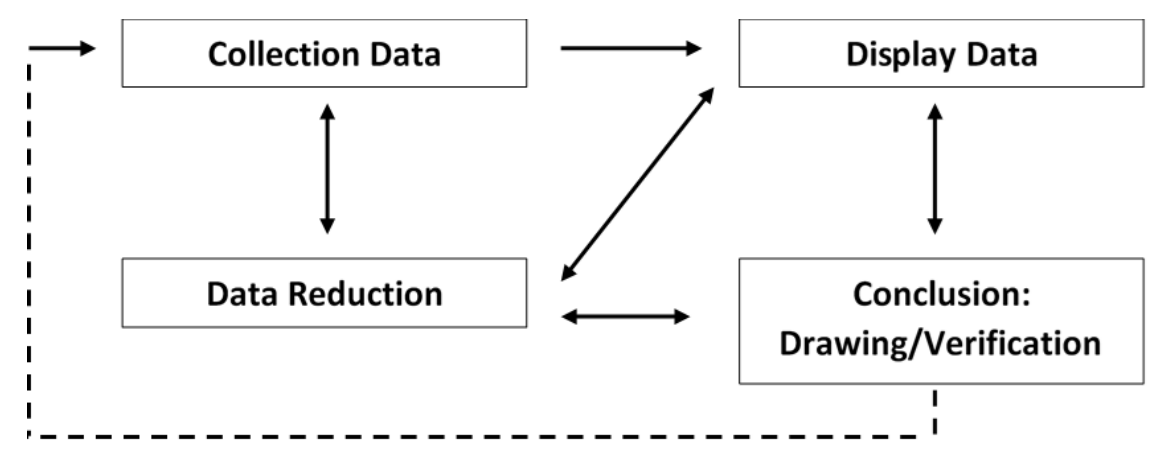

Figure 1. Miles and Huberman's Interactive Data Analysis Model.

\section{Result and Discussion}

\section{The Dynamics of the "Legacy" of the Wayang Golek Art Tradition}

The inherited tradition that we mean in the art of Wayang Golek is the presence of hereditary talents, usually within large families involved in certain fields. In its journey, the concept of heredity or what we termed inheritance does not only apply in the art of Wayang Golek but it happens to other arts. According to Chandra (2018), one of the national cultural observers, the tradition of inheritance in art is common, which can be seen from the family system of the Palembang Darussalam sultanate. However, in his late observations, this art tradition has been slightly abandoned by its lovers, which is perceived to be caused by the ignorance of the old aristocrats for this art due to the palace's lifestyle which tends to be bourgeois and the emergence of new elites with more modern ideas. Culturalists have at least detected a legacy 
system attached to certain artistic traditions from generation to generation (Wibowo, 2020). Some cultural traditions may still exist today, but not a few local traditional arts have gone out of business due to a cultural shift among today's society who are more inclined to enjoy modern art performances.

The inheritance system also applies to the case studies we found in Wayang Golek. Although there is no guarantee that the hereditary system of traditional heritage will always exist, at least most cultural practitioners experience it. One of puppeteers stated that his talents were apparently inherited by his father. His father also inherited the skills from the previous generations, and so on: "My family happens to have descendants in this art. My biological father is also a puppeteer, and he is also descended from his brother, Abah Sunarya"

The similarity of hereditary system traditions between the art of Wayang Golek and other arts is further strengthened by several discoveries by intellectuals, one of which is Al Fazri (2019). They stated that the cultural heritage of Cirebon Ancestors, the art of Brai, is a traditional art of a type of prayer which is very popular around Cirebon and Indramayu, West Java, and has become a cultural heritage from generation to generation from their ancestors. Furthermore, the preservation of this culture is perceived to be very necessary because a culture can be a bridge for the internalization of spiritual values immersed in the sholawatan lyrics into society to be closer to God and religion. Besides, Wayang Golek does not only present an artistic spectacle but also has a moral message that can be a role model for one's life, which is to have a strong, tough, and noble personality (Rianta \& Masturoh, 2013).

The inheritance system in cultural traditions stimulated the interest of scholars to explore further. One of the theories developed is the theory of heredity, which states that there is genetic transmission from parents to their offspring (Meilinda, 2017). Furthermore, this theory asserts that inherited organisms will maintain their shape from one generation to the next. These organisms are miniatures of adult organisms, and they have been formed long before. This theory may assume that the skill possessed by the informant will inevitably be maintained and exist until the next generation. However, the theory reserves pros and cons in the discourse of debate among scientists. Criticism and support in a theory is actually normal, depending on how we react to it.

In the perspective of Islamic studies, if we look at some classic books, we also find inherited traditions among the messengers, where the Prophet 
Muhammad in several hadiths did hint at the existence of a "good lineage inheritance system". Rawwas, one of the contemporary Muslim scholars in his work mentions that the concept of skill or inheritance happened in the life of the Prophet Muhammad. It could be that his ideal characteristics, such as compassion, forbearance, courage, honesty, social spirit, and others were also passed down from his ancestors, Abdullah bin Abdul Muttalib to Prophet Ibrahim (Rawwas, 1988). In the shirah literature of the Prophets, historians see an element of the tradition of "genetic inheritance" in the prophetic path. Therefore, it is no wonder if the Prophets have an unbroken lineage from the upstream to the downstream (Al-Umuri, 1994; As-Shalabi, 2008; Ghadhban, 1992).

\section{Internalization of Character Education Values in the Art of Wayang Golek}

The art of Wayang Golek is one of the efforts to instill the internalization of character education values into the community. Character education is an essential goal in the education system in Indonesia. Therefore, any efforts that can help the realization of a religious and characterized society must be maintained and optimized. Education practitioners are currently working together to find the best formula for how to build character education through various efforts (Ainiyah, 2013; Hartini et al., 2016; Lizawati \& Uli, 2018). In the art of Wayang Golek, a puppeteer actually instills good character values into the audience. Character education can be instilled through Wayang Golek performances by imitating the good characters (Rianta \& Masturoh, 2013). Some of the positive characters are strong, tough, and noble personality and sensitive to society.

Apart from being a means of internalizing good character values, Wayang Golek art can also be used as a bridge for da'wah (spreading Islamic values) to the community:

"The puppeteer has three main functions or commonly called trikaradarma in terms of padalangan (entertainer, interpreter, tinker). The entertainer, it is clear that the function of the wayang golek performance is to entertain through the storytelling and the puppet play. The panerangan interpreter, which is related to communication. The existence of the delivery of information that can be conveyed either from the government to the community or vice versa from the community to the government. In this case, a puppeteer can also be a media for preaching through wayang golek intermediaries. to convey teachings believed to be true. Long before Islam entered, the mastermind was a person who conveyed sacred teachings."

el Harakah Jurnal Budaya Islam Vol. 23 No. 2, 2021 
Walisongo in Wayang performance emphasized the urgency of the theology of shahadah, a person's statement about the belief that there is no God but Allah and that Muhammad is the messenger of Allah. This belief encouraged people towards happiness in the world and in the hereafter. This is a statement of a Muslim to live by firmly adhering to the principles of Islamic teachings to achieve success in the world and the hereafter. The internalization of religious values in certain cultures in a historical perspective has been exemplified by the Walisongo in building a religious community civilization. According to Suparjo (2008), in fostering a religious community, at least there are several strategies applied by Walisongo: 1) mosque architecture as a representation of an egalitarian social order, 2) puppet as a means of building theology and social construction, and 3) Islamic art with local cultural nuances. Puppet is apparently also used by Walisongo in social construction. In their performances, they inserted standard stories that contained the substance of social vision, such as the government system, relations with neighbours, patterns of individual and family life (Suparjo, 2008). For this purpose, Walisongo even released new figures that did not exist in the original Mahabharata or Ramayana stories. The most widely known figures are clowns which means wise mentors to the Pandavas. Walisongo introduced many Islamic teachings (aqidah, sharia, and morals) through story plots built on the behaviour of the clowns.

The dakwah of Walisongo through local culture should be appreciated and developed. Dakwah in Islamic teachings has a crucial role in educating and directing people to always follow the instructions of religious teachings (Al-Baidhawi, 1987; Az-Zuhaili, 1997). In the author's analysis, in preaching, we must follow the procedures exemplified by the Prophet, including aligning the communication style of the preacher with the listeners intellectuality (Rawwas, 1988). In certain areas, the art of Wayang Golek can be a means to deliver the teachings so that they are closer to Allah SWT, as what Walisongo did. The characters of Wayang Golek clowns adequately represent Walisongo's aspirations about the personality of a Muslim with all kinds of positions. A Muslim must have a strong personality, behave wisely, rely on God, socialize well, have high social awareness, eradicate evil, and so on. In principle, a Muslim must be able to build good relationships with fellow humans, God, and nature.

The internalization of character values through Wayang Golek must be carried out according to the darwah by the Prophet Muhammad so that the results are optimal. According to Sheikh Yusuf Khatir As-Suri in his book, 
Asalib al-Rasul fi al-Dakwah wa al-Tarbiyah, there are eight commendable characters to possess, which are compassion, patience, intelligent, humble, gentle, forgiving, with integrity, and adopting tarbiyyah (Al-Suri, 1991). The involvement of darwah in Wayang Golek performance was acknowledged by the puppeteer. According to him, the ideal puppeteer should function as a tinker, interpreter, and entertainer. In the perspective of informants who work as puppeteers, there is a great responsibility to always provide teaching and convey Islamic religious teachings to the public because, for them, it is the obligation of every individual to invite people to the goodness according to the principles of Islamic teachings.

In the context of globalization and the Covid-19 pandemic, the efforts to internalize character values continue even though they are carried out in different ways, such as through social media. The government policies to control the spread of the virus by temporarily closing cultural activities obviously changed the model of Wayang Golek performances from Live to Online. They developed a new innovation by creating Wayang Golek video contents and distributing them via YouTube and other social media.

\section{Preventive Efforts in Preserving the Art of Wayang Golek in the Modern Era and the Covid-19 Pandemic}

Since the spread of the Covid-19 virus in Indonesia, the government implemented restrictions on community activities to control the spread of the virus. President Joko Widodo took the Large-Scale Social Restriction (PSBB), which regulated more strict, disciplined, and effective physical distance restrictions. According to the government regulation no 21 of 2020, regional restrictions due to an outbreak must be determined by the Ministry of Health. The policy impacted on the closure of access to arts and culture in most parts of Indonesia, which hit the economy of traditional art activists, including those of Wayang Golek whereas Wayang Golek and other traditional arts had a great contribution to the country in terms of economy, education, and religion (Foley, 2015; Prilosadoso, 2019; Setiawan, 2019; Subiyantoro, 2020; Wardani , 2017). Furthermore, Wayang is believed by Sedana to eliminate the trauma and fear of both local and international communities after the occurrence of terrorism in Bali (Sedana, 2005).

Furthermore, other traditional arts also experience formidable challenges in maintaining their existence. Although many factors have caused the setback of traditional arts in the dimension of modernity, there are at least some 
crucial problems to resolve immediately for sustainability, which are 1) negative perception of society towards the art, that it goes against the teachings of Islam, 2) during the pandemic, crowd restriction policy also affected the closure of Wayang Golek art show. If the restriction remains too long, the traditional art industry could fail into bankrupt, 3) the characteristics of modern society who are more inclined to like modern performances., 4) the fact that the art practitioners have limited competence in digital literacy, and 5) the lack of support from the government.

To maintain the sustainability of traditional arts, serious efforts must be made jointly from practitioners, the government, and the community. The efforts may include three points: First, optimization of the traditional art, Wayang Golek, performance so that it meets the interest of the audience, which can be through innovation in packaging. In addition to presenting live performance, the artists should start developing Wayang Golek content converted into videos that can be shared on social media, such as YouTube. Second, government can help in marketing and campaign optimization by publishing Wayang Golek to not only the local community but also the international community. In addition, the government is expected to open collaborations with other relevant agencies which can open up opportunities to increase the number of requests for traditional arts. Third, community can be more open in viewing Wayang Golek. The public is required to be sensitive to this art. Keeping the art sustainable will make Indonesia a country with various cultures. Maintaining identity in the dimension of modernity will actually be an advantage. Like a business, the concept of «unique», different from the others, can be a strength. It is only a matter of how that power can be promoted to the global community.

\section{Conclusion}

Currently, traditional arts in Indonesia experience formidable challenges due to the current globalization and the penetration of the accelerated technological developments. It also changes the mindset and culture of society. This change certainly leads to the lower public interest in traditional arts, which are deemed to be "out of date" and potentially replaced by modern arts. The art of Wayang Golek is similar to the other cultural arts, where the traditions inherited from generation to generation are still embedded. Furthermore, it deserves to be preserved for its large contribution in humanizing society to become more religious. The internalization of character values is made 
inside the performance. Some of the good characters instilled are strong, wise, religious, humanist, and social. Globalization and the Covid-19 pandemic bring about a major impact on the preservation of Wayang Golek art. Therefore, serious efforts must be made to maintain its sustainability, including integral cooperation between government, community, and the artists.

\section{References}

Ainiyah, N. (2013). Pembentukan karakter melalui pendidikan agama Islam. Al-Ulum, 13(1), 25-38.

Al-Rawashdeh, M. S. (2014). The Impact of Globalization on the Political Culture of the Arab Youths. Journal of Middle Eastern and Islamic Studies (in Asia), 8(4), 81-120. https://doi.org/10.1080/19370679.2014.12023250

Albarello, F., Pianura, E., Di Stefano, F., Christofaro, M., Petrone, A., ... Velli. M.B. (2020). 2019-novel Coronavirus severe adult respiratory distress syndrome in two cases in Italy: An uncommon radiological presentation. International Journal of Infectious Diseases, 93, 192-197. https://doi. org/10.1016/j.ijid.2020.02.043

Albrow, M., Eade, J., Washbourne, N., \& Durrschmidt, J. (1994). The Impact of Globalization on Sociological Concepts: Community, Culture and Milieu. Innovation: The European Journal of Social Science Research, 7(4), 371-389. https://doi.org/10.1080/13511610.1994.9968418

Al-Baidhawi, A. bin U. bin M. A.-S. (1987). Anwar at-Tanzil wa Asrar at-Ta'wil Tafsir al-Baidhawi. Beirut: Dar Ihya' at-Turats al-Arabi.

Chandra, R. (2018). Islam Dan Warisan Kesenian Kesultanan Palembang Darussalam. Tamaddun: Jurnal Kebudayaan dan Sastra Islam, 18(1), 1-15. https://doi.org/10.19109/tamaddun.v18i1.1980

Cohen, M. (2007). Contemporary Wayang in global contexts. Asian Theatre Journal, 24(2), 338-369. https://doi.org/10.1353/atj.2007.0032

de Jonge, E., Kloppenburg, R., \& Hendriks, P. (2020). The impact of the COVID-19 pandemic on social work education and practice in the Netherlands. Social Work Education, 39(8), 1027-1036. https://doi.org $/ 10.1080 / 02615479.2020 .1823363$

el Harakah Jurnal Budaya Islam Vol. 23 No. 2, 2021 
Dewi, H. (2018). Progress study of wayang kulit in Deli Serdang regency of North Sumatera. International Journal of Civil Engineering and Technology, 9(11), 1515-1525.

Ellis, V., Steadman, S., \& Mao, Q. (2020). 'Come to a screeching halt': Can change in teacher education during the COVID-19 pandemic be seen as innovation? European Journal of Teacher Education, 43(4), 559-572. https://doi.org/10.1080/02619768.2020.1821186

Fazri, I. Al, \& Hajam. (2019). Kesenian Brai, Warisan Budaya Leluhur Cirebon. Jurnal Yaqzhan: Analisis Filsafat, Agama dan Kemanusiaan, 5(2), 103-112.

Foley, K. (2015). The Ronggeng, the Wayang, the Wali, and Islam: Female or transvestite male dancers-singers-performers and evolving Islam in west Java. Asian Theatre Journal, 32(2), 356-386. https://doi.org/10.1353/ atj.2015.0057

Ghadhban, M. M. (1992). Fiqh as-Sirah an-Nabawiyyah. Jami'ah Ummul Qura.

Hartini, H., Tryanasari, D., \& Maruti, E. S. (2016). Pendidikan Karakter Siswa Sekolah Dasar Melalui Pembelajaran Seni Budaya. Premiere Educandum : Jurnal Pendidikan Dasar dan Pembelajaran, 5(01), 128-139. https://doi. org/10.25273/pe.v5i01.329

Hasanah, N. (2019). The relation between the depth of field and the visual fatigue caused by stereoscopic Wayang Kulit shadow images. International Journal of Arts and Technology, 11(2), 139-152. https://doi.org/10.1504/ IJART.2019.098846

Kalloo, R. C., Mitchell, B., \& Kamalodeen, V. J. (2020). Responding to the COVID-19 pandemic in Trinidad and Tobago: challenges and opportunities for teacher education. Journal of Education for Teaching, 46(4), 452-462. https://doi.org/10.1080/02607476.2020.1800407

Kidd, W., \& Murray, J. (2020). The Covid-19 pandemic and its effects on teacher education in England: how teacher educators moved practicum learning online. European Journal of Teacher Education, 43(4), 542-558. https://doi.org/10.1080/02619768.2020.1820480

Law, W. W., \& Ho, W. C. (2009). Globalization, values education, and school music education in China. Journal of Curriculum Studies, 41(4), 501-520. https://doi.org/10.1080/00220270802372329 
Lis, M. (2014). Contemporary Wayang Beber in Central Java. Asian Theatre Journal, 31(2), 505-523. https://doi.org/10.1353/atj.2014.0029

Lizawati, L., \& Uli, I. (2018). Implementasi nilai pendidikan karakter dalam sastra lisan di IKIP PGRI Pontianak. Premiere Educandum : Jurnal Pendidikan Dasar dan Pembelajaran, 8(2), 140. https://doi.org/10.25273/pe.v8i2.2911

London, J. D. (2010). Globalization and the governance of education in Viet Nam. Asia Pacific Journal of Education, 30(4), 361-379. https://doi.org /10.1080/02188791.2010.520202

Mah, J. S. (2002). The impact of globalization on income distribution: the Korean experience. Applied Economics Letters, 9(15), 1007-1009. https:// doi.org/10.1080/13504850210149124

Meilinda. (2017). Teori Hereditas Mendel: Evolusi atau Revolusi (Kajian Filsafat Sains). Jurnal Pembelajaran Biologi, 4(1), 62-70.

Nalan, A. (2016). Asep Sunandar Sunarya: Dalang of wayang golek Sunda (19552014). Asian Theatre Journal, 33(2), 264-269. https://doi.org/10.1353/ atj.2016.0053

Nishiura, H., Linton, N. M., \& Akhmetzhanov, A. R. (2020). Serial interval of novel coronavirus (COVID-19) infections. International Journal of Infectious Diseases, 93, 284-286. https://doi.org/10.1016/j.ijid.2020.02.060

Poplawska, M. (2004). Wayang Wahyu as an example of Christian forms of shadow theatre. Asian Theatre Journal, 21(2), 194-202. https://doi. org/10.1353/atj.2004.0024

Prilosadoso, B. H. (2019). Wayang beber animation media as an effort for preserving wayang tradition based on information and technology. Journal of Physics: Conference Series, 1339(1). https://doi.org/10.1088/17426596/1339/1/012109

Priyanto. (2020). Seni Pertunjukan Wayang Golek Sebagai Daya Tarik Pariwisata Budaya di Saung Angklung Udjo. Jurnal Vokasi Indonesia, 8(1), 49-54.

Rawwas, M. (1988). Dirasah Tahliliyyah Li Syahshiyati ar-Rasul Muhammad. Dar an-Nafais.

el Harakah Jurnal Budaya Islam Vol. 23 No. 2, 2021 
Rianta, J., \& Masturoh, T. (2013). Penanaman Budi Pekerti melalui Pertunjukan Wayang Golek Garap Padat. GELAR Jurnal Seni Budaya, 11(1), 32-41.

Rosyadi. (2009). Wayang Golek dari Seni Pertunjukan ke Seni Kriya (Studi tentang Perkembangan Fungsi Wayang Golek di Kota Bogor). Patanjala : Jurnal Penelitian Sejarah Dan Budaya, 1(2), 135. https://doi.org/10.30959/ patanjala.v1i2.239

Sedana, I. (2005). Theatre in a time of terrorism: Renewing natural harmony after the Bali bombing via Wayang Kontemporer. Asian Theatre Journal, 22(1), 73-86. https://doi.org/10.1353/atj.2005.0012

Setiawan, D. (2019). Education and history of wayang using flash animation as media learning. International Journal of Scientific and Technology Research, 8(6), 280-283.

Subiyantoro, S. (2017). Gunungan wayang sadat: The study of its religious values and its relevance in fine art learning in high schools. Pertanika Journal of Social Sciences and Humanities, 25, 273-280.

Subiyantoro, S. (2020). Javanese cultural paradoxism: A visual semiotics study on wayang purwa characters of satria and raseksa figures. Harmonia: Journal of Arts Research and Education, 20(1), 19-28. https://doi.org/10.15294/ harmonia.v20i1.23838

Suparjo. (2008). Islam dan Budaya: Strategi Kultural Walisongo dalam Membangun Masyarakat Muslim Indonesia. Komunika: Jurnal Dakwah Dan Komunikasi, 2(2), 178-193. https://doi.org/10.24090/komunika. v2i2.100.

Asy-Syalabi, A. M. (2008). As-Sirah an-Nabiwiyyah 'Ard Waqa'i wa Tahlil Ahdats. Dar Al-Ma'rifah.

Al-Suri, Y. K. H. (1991). Asalib al-Rasul fi al-Dakwah wa al-Tarbiyah.

Thompson, M. C. (2019). the Impact of Globalization on Saudi Male Millennials' Identity Narratives. Asian Affairs, 50(3), 323-343. https://doi.org/10.1 080/03068374.2019.1636512

Utsumi, T. (2006). Global university system for engineering education in the age of globalization. European Journal of Engineering Education, 31(3), 339-348. https://doi.org/10.1080/03043790600644081 
Al-Umuri, A. D. (1994). As-Sirah an-Nabawiyyah as-Shahihah. Maktabah AlUlum Wa Al-Hikam.

Varea, V., \& González-Calvo, G. (2020). Touchless classes and absent bodies: teaching physical education in times of Covid-19. Sport, Education and Society, O(0), 1-15. https://doi.org/10.1080/13573322.2020.1791814

Wang, L., \& DeLaquil, T. (2020). The isolation of doctoral education in the times of COVID-19: recommendations for building relationships within person-environment theory. Higher Education Research and Development, 39(7), 1346-1350. https://doi.org/10.1080/07294360.2020.1823326

Wardani, N. (2017). Integrated creative learning model through suket puppet (Wayang suket) for elementary students. Pertanika Journal of Social Sciences and Humanities, 25, 217-226.

Wibowo, A. (2020). History of inheritance of Wayang Topeng Malangan (Malang traditional mask puppet) in Pakisaji and Tumpang. Harmonia: Journal of Arts Research and Education, 20(1), 73-83. https://doi.org/10.15294/ harmonia.v20i1.24785

Widjajanto, W. (2009). "Wayang authoring": A web-based authoring tool to support media literacy for children. Internetworking Indonesia Journal, $1(1), 19-24$.

Widyastutieningrum, S. R. (2018). Reviving Wayang Orang Sriwedari in Surakarta: Tourism-oriented performance. Asian Theatre Journal, 35(1), 100-111. https://doi.org/10.1353/atj.2018.0015

Zhang, S., Diao, M. Y., Yu, W., Pei, L., Lin, Z., \& Chen, D. (2020). Estimation of the reproductive number of novel coronavirus (COVID-19) and the probable outbreak size on the Diamond Princess cruise ship: A datadriven analysis. International Journal of Infectious Diseases, 93, 201-204. https://doi.org/10.1016/j.ijid.2020.02.033

Az-Zuhaili, W. bin M. (1997). At-Tafsir al-Munir fi al-Aqidah wa as-Syari'ah wa al-Manhaj. Beirut: Dar Al-Fikr al-Mu'ashir.

el Harakah Jurnal Budaya Islam Vol. 23 No. 2, 2021 
